\title{
Theoretical Studies of Colvent Effect for Oxindole Derivatives Using Polarizable Continuum Model
}

\author{
P.VIDHYA $^{1}$, V.SATHYANARAYANAMOORTH ${ }^{2 *}$ and V.KANNAPPAN ${ }^{3}$ \\ ${ }^{1}$ Research and Development Centre, Bharathiar University, Coimbatore 641 046, India. \\ ${ }^{2} P G$ and Research Department of Physics, PSG College of Arts and Science, \\ Coimbatore, 641 014, India. \\ ${ }^{3}$ Post-graduate \& Research Department of Chemistry, Presidency College, \\ Chennai, 6000055, India \\ *Corresponding author E-mail: sathyanarayanamoorthi@yahoo.co.in \\ http://dx.doi.org/10.13005/ojc/330222
}

(Received: February 27, 2017; Accepted: March 27, 2017)

\begin{abstract}
Oxindole derivatives which are commercially available have got antiviral, antifungal, antibacterial, anticancer, anti-inflammatory, antihypertensive, and anticonvulsant activities. The solvation analysis of oxindole derivatives has been carried out using B3LYP procedure with 6-311++G basis set using ten solvents to compute the electrostatic interaction, repulsive, dispersive energy and cavitation energy respectively. Studies of the electrostatic interaction of four solutes were satisfactorily correlated with dielectric constants of polar solvents. Free energy values for all the four solutes in both polar and non polar solvents were found to be negative. The negative value suggests that dissolution process in thermodynamically are feasible for all the four solutes in the investigated solvent.
\end{abstract}

Keywords: Free energy, Density Functional Theory,Oxindole, Solvation Analysis.

\section{INTRODUCTION}

Oxindoles are useful building blocks for indole chemistry. Heterocyclic compounds containing 5 to 6 membered ring are important for their diverse biological activities ${ }^{1}$. The chemistry of oxazolidinone and its derivatives have received considerable attention owing to their synthetic and biological importance. The first oxindole obtained from the condensation of isatin with indole is 3 , 3-bis(indolyl)indoline-2- prepared by Seidel in 1950. During recent years some methods have been reported for the condensation of electron-rich hetero aromatics such as indoles and pyrroles with isatins to afford their oxindole derivatives. Oxindole frameworks are found in many bioactive compounds and natural products. Due to this synthetic methods and transformations of oxindole skeletons have been extensively investigated ${ }^{2-5}$. The naturally occurring oxindole derivative convolutamydine has been 
found to exhibit potent activity in the differentiation of HL-60 human plomyelocyticleukemic cells. The varied biological activities of oxindole derivatives have attracted the synthetic chemists to a number of synthetic strategies ${ }^{6-9}$. Plant hormone, indole 3-acetic acid and animal hormone, melatonin, a potent antioxidant are the two most important indole derivatives. Fewoxindole derivatives found in marine fish and shell fish are reported to have radical scavenging activity in comparison to the powerful anti-oxidants like uric acid and indole in humans. The solubility in different solvents is an important parameter for assessing the bioavailability of pharmaceutically important organic compounds as well as in the synthesis of these compounds. Realizing the importance of the oxindole derivatives, we carried out the solvation analysis of fouroxindole compounds. The standard state of free energy solvation is a fundamental quantity that describes the energy of interaction between a solute and solvent molecules. One of the simplest methods to perform solvation analysis is the polarizable continuum model (PCM). This model envisages a solute in a cavity formed by the union of spheres centered on each atom. The procedures provide computation of the electrostatic interaction of the solute, apparent surface charges along with cavitation, dispersion and repulsion contribution ${ }^{10}$. Recently, the PCM method has been improved and extended in GAUSSIAN 03.So the cavity can be selected in numerous ways. In this paper, we report the results obtained in the quantum mechanical study of solvation of oxindolederivatives by PCM analysis and correlated free energy solution, its components with the physical properties of solvent.

\section{Method Of Computation}

The molecular structures are optimized and the optimized structures are solvated with the solvent of various dielectric constants. The physical properties such as dielectric constant,

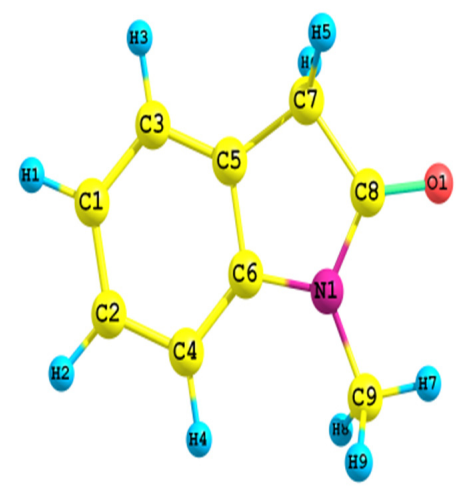

Fig. 1: Molecular Structure of 2-oxindole

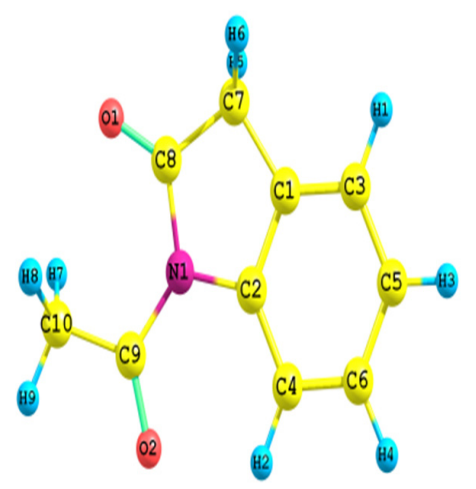

Fig. 1: Molecular Structure of 1-Methyl-2oxindole

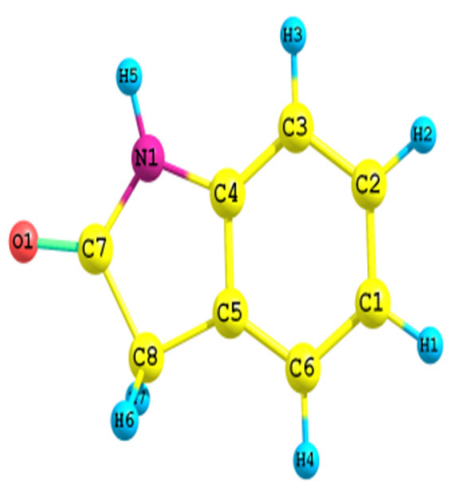

Fig. 1: Molecular Structure of 1-Acetyl-2oxindole

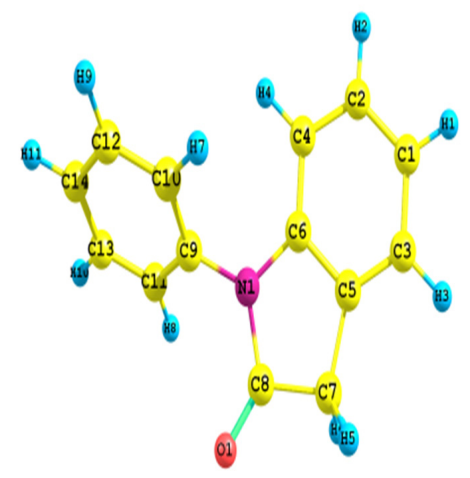

Fig. 1: Molecular Structure of 1-Phenyl-2Oxindol 
refractive index, and macroscopic surface tension of solvents are listed in Table 1. Computation has been performed with B3LYP method using $6-311++G(d, p)$ basis set to interpret the solvent effect on the behavior of the solute molecules ${ }^{11}$. The computer program GAUSSIANO $3^{12}$ was used for this purpose. The general structure of fouroxindoles and its derivatives used in the present investigation is depicted in Fig.1. In the correlation of free energy

Table 1: Solvent Descriptors

\begin{tabular}{lccccc}
\hline Solvent & $\epsilon$ & $n$ & $\mathrm{Y}$ & $\alpha$ & $\beta$ \\
\hline $\mathrm{H}_{2} \mathrm{O}$ & 78.35 & 1.33 & 71.99 & 0.82 & 0.35 \\
$\mathrm{CH}_{3} \mathrm{NO}_{2}$ & 36.56 & 1.38 & 37.48 & 0.48 & 0.41 \\
$\mathrm{CH}_{3} \mathrm{OH}$ & 32.63 & 1.33 & 22.12 & 0.43 & 0.47 \\
$\mathrm{C}_{2} \mathrm{H}_{5} \mathrm{OH}$ & 24.85 & 1.36 & 31.62 & 0.37 & 0.48 \\
$\mathrm{ACETONE}$ & 20.49 & 1.36 & 33.77 & 0.04 & 0.49 \\
$\mathrm{CH}_{2} \mathrm{CL}_{2}$ & 8.93 & 1.37 & 27.33 & 0.10 & 0.05 \\
$\mathrm{CHCL}_{3}$ & 4.90 & 1.45 & 26.53 & 0.15 & 0.02 \\
$\mathrm{TOLUENE}_{\mathrm{CLU}}$ & 2.37 & 1.50 & 40.20 & 0 & 0.14 \\
$\mathrm{C}_{6} \mathrm{H}_{6}$ & 2.27 & 1.50 & 40.62 & 0 & 0.14 \\
$\mathrm{CCL}_{4}$ & 2.23 & 1.46 & 38.04 & 0 & 0 \\
\hline
\end{tabular}

$\epsilon$ - Dielectric Constant at $298^{\circ} \mathrm{K}$.

$\mathrm{n}$ - Index of Refraction at optical frequencies at $298^{\circ} \mathrm{K}$.

Y- Macroscopic Surface Tension at a liquid air Interface.

$\alpha$ - Abraham hydrogen bond acidity.

$\beta$ - Abraham hydrogen bond basicity solution and electrostatic interaction energy, we used the polarizability which is a function of dielectric constant and these values are calculated using Claussius-Mosotti equation

$$
F(D)=(D-1 / D+2)(M / \rho)
$$

where, $\mathrm{D}=$ dielectric constant, $\mathrm{M}=$ molar mass and $\rho=$ density

\section{RESULTS AND DISCUSSIONS}

The possibility of theoretical estimation of solvent effects on the properties of molecules remains a challenge in computational chemistry because the majority of chemically and biologically important reactions occur only in solution. Free energy solution data of pharmaceutically complex solutes in different solvents and solvation analysis are useful for synthetic organic chemists as well as biochemists. It gives them an idea about the solutesolvent interaction and it can be related in the work which builds up a solute in the solvent environment. The solvation effects of oxindole derivatives are investigated using B3LYP with 6-311++G (d, p) basis set. For this purpose the components of free energy solutionssuch as electrostatic interaction, dispersive energy, repulsive energy, and cavitation energy are computed. These quantities converge quickly during a simulation and thus provide a good assessment of the computational approaches in describing solvent-solute interaction ${ }^{13}$.

Table 2: Electrostatic energy of Oxindole derivatives in various solvents at $298 \mathrm{~K}(\mathrm{~kJ} / \mathrm{mol})$

\begin{tabular}{|c|c|c|c|c|}
\hline \multicolumn{2}{|c|}{ Solvent 2 -Oxindole } & \multirow{2}{*}{$\begin{array}{c}\begin{array}{c}\text { 1- Methyl- } \\
\text { 2-Oxindole }\end{array} \\
-36.84\end{array}$} & \multirow{2}{*}{$\begin{array}{c}\begin{array}{c}\text { 1-Acetyl- } \\
\text { 2-Oxindole }\end{array} \\
-37.30\end{array}$} & \multirow{2}{*}{$\begin{array}{c}\begin{array}{c}\text { 1-Phenyl } \\
\text { 2-Oxindole }\end{array} \\
-42.66\end{array}$} \\
\hline $\mathrm{HO}_{\mathrm{O}}$ & -46.80 & & & \\
\hline $\mathrm{CH}_{3} \mathrm{NO}_{2}$ & -22.44 & -17.33 & -16.95 & -18.59 \\
\hline $\mathrm{CH}_{3} \mathrm{OH}^{2}$ & -45.29 & -35.54 & -35.96 & -41.02 \\
\hline $\mathrm{C}_{2} \mathrm{H}_{5}^{3} \mathrm{OH}$ & -44.46 & -34.83 & -35.20 & -40.14 \\
\hline ACETONE & -21.60 & -16.66 & -16.28 & -17.83 \\
\hline $\mathrm{CH}_{2} \mathrm{Cl}_{2}$ & -19.38 & -14.94 & -14.53 & -15.78 \\
\hline $\mathrm{CHCl}_{3}^{2}$ & -16.41 & -12.64 & -12.26 & -13.19 \\
\hline TOLǓENE & -10.63 & -8.1 & -7.83 & -8.33 \\
\hline $\mathrm{C}_{6} \mathrm{H}_{6}$ & -10.09 & -7.74 & -7.41 & -7.83 \\
\hline $\mathrm{CCl}_{4}$ & -9.96 & -7.66 & -7.33 & -7.79 \\
\hline
\end{tabular}


Electrostatic interaction energy is due to the dipole-dipole interaction between the solute and solvent molecules. Hence it depends mainly on the dielectric constant of the medium ${ }^{11}$. The electrostatic energy values are computed in ten solvents and presented in Table 2. It may be pointed out that electrostatic interaction energy values are less in polar solvents and slightly higher in non-polar solvents in the case of all fouroxindole compounds. In solvents like water and alcohols there is a possibility of intermolecular hydrogen bonding, which is also a type of strong dipole-dipole interaction. This may be the reason for the high electrostatic interaction of the oxindole derivatives in water and alcoholic solvents. The data in Table 2 suggests that the electrostatic contribution in a given solvent depends on the structure of the solute. Plots of electrostatic energy against dielectric constant of the four systems are depicted in Fig 2. These plots indicate that the electrostatic energy is negative in all the four solutes and solvents investigated. Further, the negative value increases with an increase in dielectric constant of the solvent. Thus, the negative values of electrostatic interaction increases from $\mathrm{CCl}_{4}$ to water. The present investigation envisages that the electrostatic interaction is more negative inwater than other compounds due to hydrophobic effect.

The dispersion energy is due to the polarization of the solute molecules by the solvent

Table 3: Dispersive Energy of Oxindole derivatives in various solvents at $298 \mathrm{~K}(\mathrm{~kJ} / \mathrm{mol})$

\begin{tabular}{llccc}
\hline Solvent & 2-Oxindole & $\begin{array}{c}\text { 1- Methyl- } \\
\text { 2-Oxindole }\end{array}$ & $\begin{array}{c}\text { 1-Acetyl- } \\
\text { 2-Oxindole }\end{array}$ & $\begin{array}{c}\text { 1-Phenyl } \\
\text { 2-Oxindole }\end{array}$ \\
\hline $\mathrm{H}_{2} \mathrm{O}$ & -85.85 & -94.06 & -101.01 & 121.44 \\
$\mathrm{CH}_{3} \mathrm{NO}_{2}$ & -75.60 & -82.80 & -82.80 & 106.91 \\
$\mathrm{CH}_{3} \mathrm{OH}$ & -73.63 & -80.66 & -80.66 & 104.15 \\
$\mathrm{C}_{2} \mathrm{H}_{5} \mathrm{OH}$ & -75.18 & -82.38 & -82.38 & -106.32 \\
$\mathrm{ACETONE}$ & -68.32 & -74.85 & -74.85 & 96.61 \\
$\mathrm{CH}_{2} \mathrm{Cl}_{2}$ & -69.70 & -76.27 & -76.27 & 98.54 \\
$\mathrm{CHCl}_{3}$ & -62.25 & -68.06 & -68.06 & -87.99 \\
$\mathrm{TOLUENE}_{\mathrm{O}}$ & -83.05 & -90.96 & -90.96 & 117.46 \\
$\mathrm{C}_{6} \mathrm{H}_{6}$ & -81.29 & -89.08 & -89.08 & 115.03 \\
$\mathrm{CCl}_{4}$ & -62.83 & -68.69 & -68.69 & 88.83 \\
\hline
\end{tabular}

Table 4: Repulsive Energy of Oxindole derivatives in various solvents at $298 \mathrm{~K}(\mathrm{~kJ} / \mathrm{mol})$

\begin{tabular}{lcccc}
\hline Solvent & 2-Oxindole & $\begin{array}{c}\text { 1- Methyl- } \\
\text { 2-Oxindole }\end{array}$ & $\begin{array}{c}\text { 1-Acetyl- } \\
\text { 2-Oxindole }\end{array}$ & $\begin{array}{c}\text { 1-Phenyl } \\
\text { 2-Oxindole }\end{array}$ \\
\hline $\mathrm{H}_{2} \mathrm{O}$ & 19.38 & 20.47 & 19.76 & 26.37 \\
$\mathrm{CH}_{3} \mathrm{NO}_{2}$ & 15.78 & 16.66 & 16.20 & 21.47 \\
$\mathrm{CH}_{3} \mathrm{OH}$ & 15.91 & 16.79 & 16.24 & 21.64 \\
$\mathrm{C}_{2} \mathrm{H}_{5} \mathrm{OH}$ & 15.99 & 16.87 & 16.33 & 21.77 \\
$\mathrm{ACETONE}$ & 14.06 & 14.86 & 14.36 & 19.13 \\
$\mathrm{CH}_{2} \mathrm{Cl}_{2}$ & 12.56 & 13.23 & 12.98 & 17.08 \\
$\mathrm{CHCl}_{3}$ & 10.26 & 10.80 & 10.63 & 13.94 \\
$\mathrm{TOLUENE}$ & 24.11 & 25.49 & 25.49 & 32.78 \\
$\mathrm{C}_{6} \mathrm{H}_{6}$ & 23.78 & 25.16 & 25.16 & 32.36 \\
$\mathrm{CCl}_{4}$ & 10.09 & 10.59 & 10.59 & 13.69 \\
\hline
\end{tabular}


molecules. The computed dispersion energy values of the fouroxindole derivatives in various solvents are given in Table 3. It is evident from the data presented in Table 3 that there is no significant difference in the dispersion energies in protic solvents of varied dielectric constants. These data also suggest that the dispersion energy is influenced by the polarizability of the solvent which in turn depends upon the size. The plot of dispersive energy against the polarizability function $F(D)$ is presented in

Table 5: Cavitation energy of Oxindole derivatives in various solvents at $298 \mathrm{~K}(\mathrm{~kJ} / \mathrm{mol})$

\begin{tabular}{lcccc}
\hline Solvent & 2-Oxindole & $\begin{array}{c}\text { 1- Methyl- } \\
\text { 2-Oxindole }\end{array}$ & $\begin{array}{c}\text { 1-Acetyl- } \\
\text { 2-Oxindole }\end{array}$ & $\begin{array}{c}\text { 1-Phenyl } \\
\text { 2-Oxindole }\end{array}$ \\
\hline $\mathrm{H}_{2} \mathrm{O}$ & 73.51 & 82.00 & 93.18 & 109.42 \\
$\mathrm{CH}_{3} \mathrm{NO}_{2}$ & 63.08 & 70.32 & 79.95 & 93.81 \\
$\mathrm{CH}_{3} \mathrm{OH}$ & 53.29 & 59.40 & 67.52 & 79.20 \\
$\mathrm{C}_{2} \mathrm{H}_{5} \mathrm{OH}$ & 54.33 & 60.57 & 68.86 & 80.79 \\
$\mathrm{ACETONE}$ & 52.28 & 58.27 & 66.22 & 77.69 \\
$\mathrm{CH}_{2} \mathrm{Cl}_{2}$ & 54.59 & 60.82 & 69.15 & 81.12 \\
$\mathrm{CHCl}_{3}$ & 53.04 & 59.06 & 67.15 & 78.78 \\
$\mathrm{TOLUENE}$ & 58.85 & 65.51 & 74.51 & 87.40 \\
$\mathrm{C}_{6} \mathrm{H}_{6}$ & 59.82 & 66.64 & 75.77 & 88.87 \\
$\mathrm{CCl}_{4}$ & 55.05 & 61.28 & 69.70 & 81.75 \\
\hline
\end{tabular}

Table 6: Free energy of Oxindole derivatives in various solvents at $298 \mathrm{~K}(\mathrm{~kJ} / \mathrm{mol})$

\begin{tabular}{lcccc}
\hline Solvent & 2-Oxindole & $\begin{array}{c}\text { 1- Methyl- } \\
\text { 2-Oxindole }\end{array}$ & $\begin{array}{c}\text { 1-Acetyl- } \\
\text { 2-Oxindole }\end{array}$ & $\begin{array}{c}\text { 1-Phenyl } \\
\text { 2-Oxindole }\end{array}$ \\
\hline $\mathrm{H}_{2} \mathrm{O}$ & -39.77 & -28.38 & -25.33 & -28.30 \\
$\mathrm{CH}_{3} \mathrm{NO}_{2}$ & -19.13 & -13.10 & -9.84 & -10.21 \\
$\mathrm{CH}_{3} \mathrm{OH}$ & -49.73 & -40.02 & -38.89 & $-4 \quad 4.29$ \\
$\mathrm{C}_{2} \mathrm{H}_{5} \mathrm{OH}$ & -49.31 & -39.73 & -38.55 & -43.95 \\
$\mathrm{ACETONE}$ & 23.57 & -18.38 & -16.07 & -17.62 \\
$\mathrm{CH}_{2} \mathrm{Cl}_{2}$ & -21.89 & -17.12 & -14.61 & -16.12 \\
$\mathrm{CHCl}_{3}$ & -15.36 & -10.84 & -7.91 & -8.50 \\
$\mathrm{TOLUENE}$ & 10.72 & -8.12 & -6.11 & -5.61 \\
$\mathrm{C}_{6} \mathrm{H}_{6}$ & -7.79 & -5.02 & -2.76 & -1.63 \\
$\mathrm{CCl}_{4}$ & -7.66 & -4.44 & -1.30 & -1.13 \\
\hline
\end{tabular}

Table 7: Dipole moment of the oxindole derivatives in Debyes

\begin{tabular}{lc}
\hline Compound Name & Dipole moment Value \\
\hline 2-Oxindole & 3.1379 \\
1-Methyl-2-Oxindole & 2.8790 \\
1-Acetyl-2-Oxindole & 2.5566 \\
1-Phenyl-2-Oxindole & 3.0600 \\
\hline
\end{tabular}

Fig3. The plots of different solutes almost overlap indicating that a structural variationin solute does not influence the dispersion energy. From the table 3 we observe that the dispersive energy is higherin chlorinated solvents than in any other solvents studied here. The same trend has been observed for all the solute molecules. This may be due to the interaction between electronegative atoms in solvent molecules and solute molecules. 
Table: 8 Induced dipole moment of Oxindole derivatives in various solvents at $298 \mathrm{~K}(\mathrm{~kJ} / \mathrm{mol})$

\begin{tabular}{lcccc}
\hline Solvent & 2-Oxindole & $\begin{array}{c}\text { 1- Methyl- } \\
\text { 2-Oxindole }\end{array}$ & $\begin{array}{c}\text { 1-Acetyl- } \\
\text { 2-Oxindole }\end{array}$ & $\begin{array}{c}\text { 1-Phenyl } \\
\text { 2-Oxindole }\end{array}$ \\
\hline $\mathrm{H}_{2} \mathrm{O}$ & 3.82 & 3.67 & 3.75 & 4.49 \\
$\mathrm{CH}_{3} \mathrm{NO}_{2}$ & 3.70 & 3.50 & 3.36 & 4.07 \\
$\mathrm{CH}_{3} \mathrm{OH}$ & 3.80 & 3.65 & 3.71 & 4.44 \\
$\mathrm{C}_{2} \mathrm{H}_{5} \mathrm{OH}$ & 3.80 & 3.63 & 3.69 & 4.41 \\
$\mathrm{ACETONE}$ & 3.68 & 3.48 & 3.33 & 4.03 \\
$\mathrm{CH}_{2} \mathrm{Cl}_{2}$ & 3.63 & 3.42 & 3.24 & 3.93 \\
$\mathrm{CHCl}_{3}$ & 3.57 & 3.34 & 3.13 & 3.79 \\
$\mathrm{TOLUENE}$ & 3.43 & 3.18 & 2.92 & 3.53 \\
$\mathrm{C}_{6} \mathrm{H}_{6}$ & 3.41 & 3.16 & 2.90 & 3.50 \\
$\mathrm{CCl}_{4}$ & 3.41 & 3.16 & 2.90 & 3.50 \\
\hline
\end{tabular}

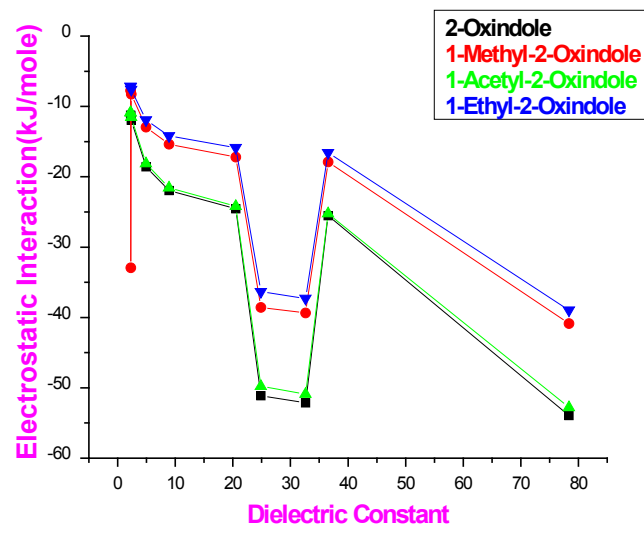

Fig. 2: Plots of electrostatic energy versus dielectric constant of solvent

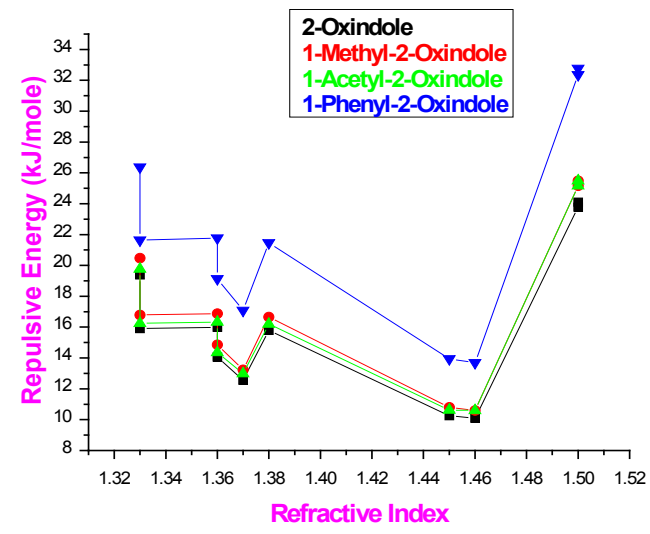

Fig. 4: Plots of repulsion energy versus refractive index of solvent

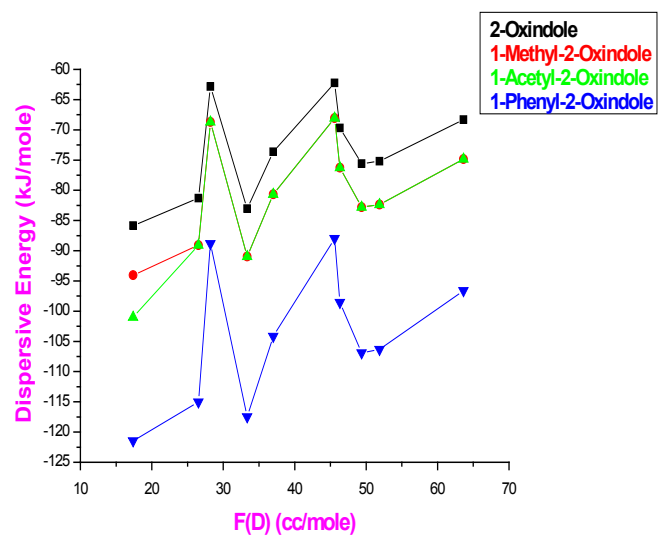

Fig. 3: Plots of dispersive energy versus polarizability function $[F(D)]$ solvent

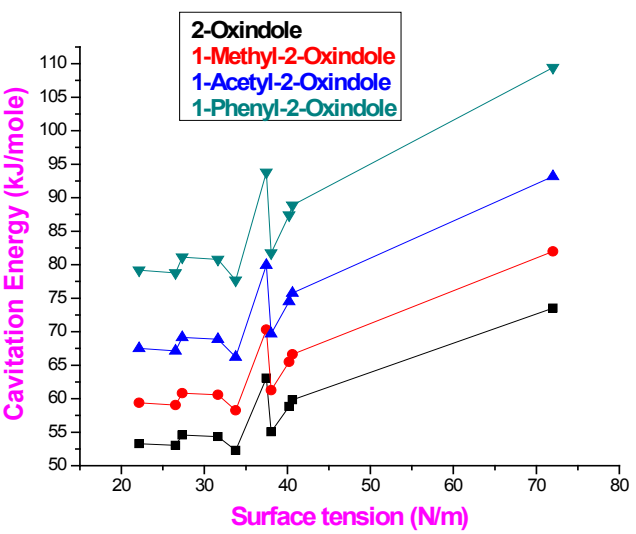

Fig. 5: Plots of Cavitation energy versus refractive index solvent 


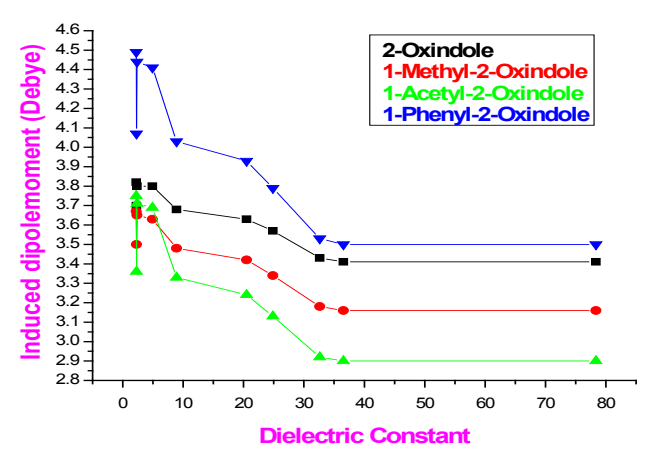

Fig. 6: Plots of Induced dipole moment versus dielectric constant solvent

The repulsive energy between solute and solvent molecules is another important parameter to be considered in solvation analysis. Table 4 shows computed values of repulsive energies of the four solute molecules in ten different media. It is noted that the repulsive energies formed due to solute-solvent interactions had positive values in the solvents. Plots of repulsive energy against refractive index of the solvent of the three solutes are given in Fig 4. From this we observe that the repulsive energy is almost correlated with the refractive index of the solvent except Nitro methane. This may be due to high repulsive negative -ion present in the dichloromethane. By relating the refractive index of the solvent with the repulsive energyit is found that there is a uniform increase in repulsive energy. However, in the case of aromatic solvents, there is an abrupt increase of repulsive energy in all the solutes. Even though ethanol and acetone have same refractive index, there is a variation in the repulsive energies of the oxindole derivatives due to the macroscopic surface tension of the solvent molecules. This might be owing to the fact that both the solute and aromatic hydrocarbon solvents contain $\Pi$-electrons and a repulsive force between them.

The cavitation free energy is a contribution of the solvation free energy. If the cavitation energy is more positive it will reduce the negative value of free energy solution and will influence the solubility. The values of cavitation energy are computed for the fouroxindole compounds in different solvents at $298 \mathrm{~K}$ by B3LYP method with $6-311++G(d, p)$ basis set and listed in Table 5. It can be seen that cavitation energy is positive for the four solutes in all the ten solvents at $298 \mathrm{~K}$. Analysis of cavitation energy data in Table 5 reveals that the cavitation energy correlated with macroscopic surface tension depends on the structure of solute, nature of solvent and macroscopic surface tension of solvent.Fig.5 showsplots of cavitation energy graph versus surface tension graph.

The molecular free energy in solution can be written as a sum of four contributions

$$
\Delta \mathrm{G}_{\text {solv }}=\Delta \mathrm{G}_{\text {ele }}+\Delta \mathrm{G}_{\text {disp }}+\Delta \mathrm{G}_{\text {rep }}+\Delta \mathrm{G}_{\text {cav }}
$$

Where $\Delta G_{\text {ele }}$ is the electrostatic contribution, $\Delta G_{\text {cav }}$ is a positive term corresponding to the work spent in forming a suitable cavity in the medium. $\Delta G_{\text {disp }}$ is the dispersion contribution due to the coupling work and $\Delta G_{\text {rep }}$ is a repulsion term due to the non covalent interactions. $\Delta G_{\text {cav }}$ is the work needed to form the cavity. The dispersion-repulsion terms are calculated adopting the atom-atom potential parameters proposed by Caillet and Claverie ${ }^{17-19}$. Table 6 shows how the different characteristic of each solvent affects the free energy salvation of the four selected molecules. For example benzene \& toluene have similar refractive index but benzene hashigh favorable free energy solvation than toluenebecause of increased favorable electrostatic interactions. For solvents $\mathrm{CH}_{2} \mathrm{Cl}_{2} \& \mathrm{CHCl}_{3}$ the refractive index is lower than benzene refractive index. In addition to hydrogen bond basicity parameter, benzene provideshigh favorable free energy solvation due to higher macroscopic surface tension and its basicity parameter. From the study we observe that the free energy solvation of all the four molecules of water iscomparatively less favourablethan that of the other solvents because of the hydrophobic effect. But Table 6 shows that the free energy solvation in methanol \& ethanol are least favorable out of all the solvents listed.And this favorable interaction isoutweighted by the hydrophobic contribution. The present study of the solute-solvent interaction is mainly due to dipole-dipole attraction. In order to express the solute-solvent interaction, the dipole moment and Induced dipole moment values are calculated and listed in Table 7 \&8. The Induced dipole moment of a given solute slightly increases with dielectric constant of the solvent. The induced dipole moment with the dielectric constant of the solvent in Fig.6 shows plots of Induced dipole moment against 
dielectric constant of the solvent. Polar solvents have large dipole moments and contain bonds between atoms with very different electro negativities, such as oxygen and hydrogen.

\section{CONCLUSION}

We have adopted a reliable self consistent field method, which combines a Polarizable Continuum Model of the solvent with DFT for the solute to calculate the solvation free energy and its component in various solvents. The electrostatic interaction contribution of the free energy can be satisfactorily correlated with the dielectric constant of the solvent. Although their dielectric constants are small, the dispersive energy is high for the four solutes in $\mathrm{CCl}_{4}$ among organic solvents. The correlation between repulsive energy and refractive index of the solvent is fairly satisfactory. $\Delta \mathrm{G}_{\text {solv }}$ values of the four solutes in different media are computed by summing up the component energies. The values of the free energy solution of the four solutes in all the ten solvents are negative. It suggests that the dissolution process is thermodynamically feasible for the four solutes in the investigated solvents. The induced dipole moments are high in polar solvents and for a given solute it is highest in water and lowest in $\mathrm{CCl}_{4}$

\section{REFERENCES}

Chevan, P.; Mane, A.S.; Shingare, M.S.; Indian J. Chem. 2001, 408, 339.

Zhou, F.; Liu,Y.L.; Zhou, J. Adv. Synth. Catal.2010, 352, 1381-1407. Huters, A.D.; Styduhar, E.D.; Garg, Angew. N.K.; Chem. Int. Ed. 2012, 51,3758-3765. Ball-Jones, N.R.; Badillo, J.J.; Franz, A.K.; Org. Biomol. Chem.2012, 10, 5165-5181.

Dalpozzo, R.; Bartoli, G.; Bencivenni, G.; Chem. Soc. Rev.2012,41, 7247-7290. Jursic, B.; Stevens, E.D.; Tetrahedron Lett.2002,43,5681-5683.

Azizian, J.; Mohammadi, A.A.; Karimi, N.; Mohammadizade, M.R.; Karimi, A.R.; Catal. Commun.2006, 7,752-755.

Wang, S.Y.; JiS. J., Tetrahedron, 2006, 62,1527-1535.

Yadav, J. S.; Reddy, B.V.S.; Gayathri, K.U., Meraj, S.; Prasad, A.R.; Synthesis, 2006,4.,121-4123.

Sathyanarayanamoorthi, V.; Sukumaran, K.; Kannappan, V.; Brindha, S.; J. Mol. Liq.2011, 160, 125-129.

1 Winget, P.; Thompson, J.D.; Cramer, C.J.; Truhlar, D.G.; J. Phys. Chem.2002, 10651605168.

Frisch, M.J.; Trucks, G.W.; Schlegel, H.B.; Scuseria, G.E.; Robb, M.A.; J.R. Cheeseman,
J.R.; Montgomery J.A.; Vreven, T.; Kudin, K.N.; Burant, J.C.; Millam, J.M.; lyengar, S.S. ; Tomasi, J.; Barone, V.; Mennucci, B.; Cossi, M.; Scalmani, G.; Rega, N.; Petersson, G.A. ; Nakatsuji, H.; Hada, M.; Ehara, M.; Toyota, K.; Fukuda, R.; Hasegawa, J.; Ishida, M.; Nakajima, T.; Honda, Y.; Kitao, O.; Nakai, H.; Klene, M.; Li, X.; Knox, J.E.; Hratchian, H.P.; Cross, J.B.; Adamo, C.; Jaramillo, J.; Gomperts, R.; Stratmann, R.E.; Yazyev, O. ; Austin, A.J.; Cammi, R. Pomelli, C.; Ochterski, J.W.; Ayala, P.Y.; Morokuma, K..; Voth, G.A. .; Salvador, P.; Dannenberg, J.J.; Zakrzewski, V.G.; Dapprich, S.; Daniels, A.D.; Strain, M.C.; Farkas, O.; Malick, D.K.; Rabuck, A.D.; Raghavachari, K.; Foresman, J.B.; Ortiz, J.V.; Cui, Q.; Baboul, A.G.; Clifford, S.; Cioslowski, J.; Stefanov, B.B.; Liu, G.; Liashenko, A.; Piskorz, I.; Komaromi, R.L.; Martin, D.J.; Fox, T.; Keith, M.A.; Al-Laham, C.Y. Peng, Nanayakkara, A.; Challacombe, M.; Gill, P.M.W.; Johnson, B.; Chen, W.; Wong,M.W.; Gonzalez, C.; Pople, J.A.;Gaussian 03, Revision B.01, Gaussian, Inc., 2003.

Elena Cuhero, F.; Javier Lugne, Modesto Orozco, JialiGao, J. Phys. Chem., 2003, B107, 1664-1671. 